DOI 10.37882/2223-2982.2021.04-2.08

\title{
ПРИНЯТИЕ М.К. ТЕНИШЕВОЙ ПЕДАГОГИЧЕСКОЙ ИДЕИ К.Д. УШИНСКОГО 0 «ВЕЛИКИХ ВОСПИТАТЕЛЯХ»
}

\section{K.D. USHINSKY ABOUT "GREAT EDUCATORS"}

A. Zhbankov

Summary: The article highlights the idea of K.D. Ushinsky about the external factors of education: nature, life, science, religion, as well as the role of publicschools in preparing for the perception of their influence. The facts illustrating the reflection of this idea in the process of functioning of the Talashkin agricultural School, created by Princess M.K. Tenisheva, are presented.

Keywords: education, folk school, nature, life, science, religion, K.D. Ushinskiy, M.K. Tenisheva.
$\mathrm{K}$ нягиня М.К. Тенишева вошла в историю народного образования России конца XIX - начала XX веков как представитель активной организационно-педагогической деятельности, предметом которой явилось образование крестьянских детей.

Мария Клавдиевна не имела специального педагогического образования. Отсутствуют официальные сведения об ее самообразовании в данной области. В самоописании жизнедеятельности М.К. Тенишевой нет упоминаний об ученых-педагогах того времени. Однако, заметны следы передовых педагогических идей, особенно К.Д. Ушинского, которые проявились как в ее взглядах, так и в ее организационно-педагогической деятельности, связанной с организацией в Смоленской губернии Талашкинской сельскохозяйственной школы. Такие следы могут свидетельствовать о субъективном восприятии, принятии таких идей и оперировании ими.

Анализ документов, литературных и публицистических источников, прежде всего книги самой Тенишевой «Впечатления моей жизни» показал, что особо значимыми для нее были идеи К.Д. Ушинского о воспитании в народных школах. Например, к таким положениям относится идея о факторах воспитания - великих воспитателях, выраженная им в контексте с организацией народных школ.

«Духовное развитие, духовное воспитание человека в отдельности и народа вообще, - писал К.Д. Ушинский, совершается не одной школой, но несколькими великими воспитателями: природой, жизнью, наукой и религией» [4]. Ученый-педагог называет условие, при котором жбанков Алексей Алексеевич

Аспирант, Смоленский Государственный Университет al_zh_xx@mail.ru

Аннотация: В статье освещается идея К.Д. Ушинского о внешних факторах воспитания: природе, жизни, науке, религии, а также о роли народных школ в подготовке к восприятию их влияния. Приводятся факты, иллюстрирующие отражения данной идеи в образовательном процессе Талашкинской сельскохозяйственной школы, созданной княгиней М.К. Тенишевой.

Ключевые слова: воспитание, народная школа, природа, жизнь, наука, религия, К.Д. Ушинский, М.К. Тенишева.

они оказывают воспитывающее влияние на ребенка: «... не трудно убедиться также, что уроки этих великих воспитателей человека производят на его душу развивающее влияние только тогда, когда душа эта хоть скольконибудь к тому подготовлена» [4].

По мнению Константина Дмитриевича, подготовку восприятия крестьянскими детьми влияний «великих воспитателей» должна обеспечить народная школа, «... которая бы внесла в наши села и деревни здоровое первоначальное воспитание, открыла зрение и слух, душу и сердце народа урокам наставников человечества: природе, жизни, науке и христианской религии [4].

К.Д. Ушинский подчеркивал, что «Природа, говорящая столь красноречива образованному уму и развитому сердцу, остается немой для полудикого человека, который, как животное, подчиняется ее влиянию, не извлекая из этого влияния ни новых мыслей, ни новых чувств» [4].

Княгине М.К. Тенишевой близка и понятная мысль К.Д. Ушинского, так как она имела богатый жизненный опыт испытания рационального и эмоционального влияния природы на ее внутренний мир. В своей книге княгиня приводит многочисленные ситуации, в которых она испытывала влияние природы. В текст статьи мы включили ситуацию весенней прогулки на пароходе по реке Десна. «После Брянска мы вошли в широкую равнину. Справа, слева до горизонта разливался перед нами океан. Только кое-где торчали из воды макушки деревьев, да чернели верхи затопившихся стогов. Местами водное пространство незаметно суживалось, чувствовались берега, 
заросшие кустами, окутанные бледно-зеленой дымкой. Искрящаяся мелкая рябь на воде блестела на солнце, а теплый ветерок ласково щекотал лицо. Мы были прикованы этим зрелищем. Для слов и восторга не было места. О Русь, дорогая...я люблю тебя в этой торжественной и святой простоте...» [3].

Для постройки типового здания Талашкинской сельскохозяйственной школы княгиня купила усадьбу на хуторе Фленово, имевшую богатую природную среду. Возле усадьбы была «...высокая гора, на которой росли огромные ели, сосны и липы...вид с горы был действительно редким по красоте. По огромному необъятному пространству, по мягким склонам холмов ютились деревушки среди самых разнообразных и разноцветных полей, разбросанных как ковер, горящие на солнце прихотливыми пятнами во всех направлениях. Кое-где между ними виднелись небольшие перелески, на горизонте тянулся лес темно-синей полоской. Даль необъятная, теряющаяся в темной дымке, простор и покой...» [3, с. 141]. Естественную природу дополнял участок с липовой аллеей, а также созданные руками учеников природные объекты - учебный сад, огород, поля с различными зерновыми культурами, посевные луга, питомник.

Постоянное соприкосновение с естественной природной средой и участие в создании рукотворной природной среды проявили себя как средства подготовки учеников к взаимодействию с природой в будущей жизни.

В этом плане М.К. Тенишева соглашалась с великим Ушинским, считавшим что «Жизнь конечна, учит многому и самых грубых людей, но, тогда как подготовленный воспитанием человек из первых же жизненных опытов извлекает плодотворную мысль и, сообразив в чем дело, быстро овладевает своим положением» [4]. В жизни, по мнению Константина Дмитриевича, подготовить человека в юном возрасте может только сознательное воспитание и разумное обучение [4]. Крестьянскому населению России традиционно был характерен особый образ жизни, основным содержанием которого был сельскохозяйственный труд, который заметно усложнился с переходом на рыночные отношения и резким скачком технологии и техники сельскохозяйственного производства. Поэтому вопрос о подготовке к нему в школе значительно актуализировался. Княгиня М.К. Тенишева хорошо это понимала. Воспитание и профессиональное обучение в ее сельскохозяйственной школе имели ярко выраженную направленность на подготовку к сельскохозяйственному труду, а также к сопровождающим его ремеслам, устройству крестьянского быта.

«Настоящая основная цель школы, - написано в годовом отчете за 1904 год Талашкинской сельскохозяйственной школы княгини М.К. Тенишевой, - подготовить из своих воспитанников способных людей как к ведению собственного хозяйства, так и к выполнению различных обязанностей по сельскому хозяйству в частных имениях в качестве экономических старост, приказчиков, помощников, управляющих, и тому подобному» $[2$, с. 5].

В соответствие с целью в школе изучались такие предметы, как полеводство, луговодство, садоводство, огородничество, скотоводство (овцеводство, коневодство, свиноводство, ветеринария), земледелие, геодезия, черчение. Были открыты слесарная, столярная, плотницкая, кузнечная, шорная мастерские, а для девочек - рукодельная мастерская.

Теоретическое обучение на уроках сопровождалось практическими работами под руководством преподавателей-специалистов. В учебных целях на школьном участке были созданы три образцовых хозяйства.

О качестве подготовки учеников к ожидающей их самостоятельной жизни и хозяйственной деятельности свидетельствует высокая урожайность сельскохозяйственных культур на учебных участках, а также высокий потребительский спрос на сделанные учениками предметы быта на выставках и в московском магазине «Родник», открытом княгиней.

«Что наука, в тесном смысле слова, остается немой и бесполезной для не подготовленных понимать ее наставлений, об этом не может быть и речи...книга, имеющая столь важное значение для человека, сколько-нибудь тронутая развитием, также как природа и опыты жизни, остается немой для того, кто, прочитав механически страницу, не сумеет извлечь из мертвой буквы живой мысли...нет, книгами нельзя развивать просвещение в народе, лишенном сколько-нибудь разумного первоначального воспитания» [4]. Эти слова возвращают нас к идее К.Д. Ушинского о том, что к восприятию крестьянскими детьми уроков науки как великого учителя, так же как и уроков природы и жизни, должна подготовить народная школа.

Говоря о науке в «тесном» смысле слова, ученый-педагог имел ввиду результаты научной деятельности - теорию, которую он понимал, как связь фактов в идеальной форме, идеальную сторону практики [4]. В статье «О пользе педагогической литературы» К.Д. Ушинский показал взаимосвязь теории и практики, роль педагогической теории в педагогической практике. Его выводы относятся к любому виду деятельности, в том числе и к сельскохозяйственному труду.

В школе М.К. Тенишевой изучались теоретические сведения из естественных и сельскохозяйственных наук. По специальным предметам большая часть времени отводилась на получение научных знаний предписываю- 
щего характера по сельскохозяйственным технологиям и техникам, известных в конце XIX - начале XX веков. B отчетах школы подробно описывается содержание сельскохозяйственной практики, свидетельствующее о том, что при проведении сельскохозяйственных работ на учебных участках использовались полученные современные знания.

В Талашкинской школе обращалось внимание не только на теоретическую подготовку учеников с учетом возраста и уровня образования, но и на элементарную подготовку к исследовательской деятельности. Ученики проводили простейшие сельскохозяйственные опыты по выбору способа удобрения картофеля, по определению семян трав, наиболее пригодных к посеву на школьных лугах.

При школе работали метеостанция, где ученики во время дежурства работали помощники метеоролога и пчелиный музей. Они могли посещать археологический музей в имении попечительницы.

«Всего более образующей силой для простого народа имеет церковь. Она своими внешними формами, полными глубоким смыслом, так сказать, улавливает полудикого человека с внешней его стороны с тем, чтобы потом поднять его на высшую ступень самосознания...в этом отношении разумное первоначальное воспитание дает человеку достаточно пытливости и умственной силы для того, чтобы не остановиться на одних формах, не принять формы за сущность...» [4].

В Талашкинской школе изучение Закона Божьего было обязательным. Кроме того, в школе было введено церковное пение. Ближайший храм находился в пяти верстах от школы. «По воскресеньям и праздникам мои ученики ходили петь в Знаменскую церковь», - вспоминала М.К. Тенишева [3, с.53]. «Под каждый праздник в школе...совершались всенощные бдения, после которых священник, законоучитель В.Е. Дьяконов, перед двунадесятыми праздниками говорил ученикам о значении предстоящего праздника и его происхождении. Во время церковных служб поет хор учеников под управлением преподавателя» [3, с. 183].

Княгиня захотела, чтоб при школе был «Божий Храм на горе». «Хотела, чтобы дело любви - школу увенчать негасимой лампадой - церковью. Хотелось, чтобы десница Господня с вершины этой горы из века в век благословляла создание любви - народную школу, где...из темных дикарей выходили люди...» [3, с. 189].

Построенный храм Святого Духа стал «последней точкой» в участии Марии Клавдиевны в строительстве народного образования в России.

ЛИТЕРАТУРА

1. Годовой отчет за 1903 год о состоянии Талашкинской низшей сельскохозяйственной школы 1-го разряда, учрежденной княгиней М.К. Тенишевой. Смоленск, 1904. - 63 с.

2. Годовой отчет за 1904 год о состоянии Талашкинской низшей сельскохозяйственной школы 1-го разряда, учрежденной княгиней М.К. Тенишевой. Смоленск, 1905. - 63 с.

3. Тенишева М.К. Впечатления моей жизни. М.: Искусство, 1991. - 287 с.

4. Ушинский К.Д. Вопросы о народных школах. Собрание сочинений. Т.2. М.: Академия педагогических наук, 1948. С. 252 - 262.

(с) Жбанков Алексей Алексеевич (al_zh_xx@mail.ru). 